\title{
顎変形症患者の心理 \\ Psychological status of patients with jaw deformities
}

小林 正治

Tadaharu Kobayashi 新潟大学大学院医歯学総合研究科 組織再建口腔外科学分野 Division of Reconstructive Surgery for Oral and Maxillofacial Region, Niigata University Graduate School of Medical and Dental Sciences

末石 研二

Kenji Sueishi

東京歯科大学 歯科矯正学講座

Department of Orthodontics, Tokyo Dental College

近年，顎変形症患者に対する外科的矯正治療の社会的認知度の上昇に伴い医療機関を受診する患者 数は増加傾向にあり，その主訴も多様化してきています。外科的矯正治療の目的は，顎変形に起因し た機能的ならびに審美的な問題を改善することですが，患者の多くは審美的改善のために本手術を希 望し，特に心理学的に問題を抱えている患者においては術後の満足度が低くなる傾向にあることが報 告されています。外科的矯正治療は，一般的な手術とは異なり，患者自身の意思に依存する高度に選 択的な手術であることから，受診の動機自体が治療必要性の根拠となり，治療結果に対する患者の満 足度にも大きくかかわるものと考えられます。したがって，治療方針の決定では本疾患患者が有する 形態的ならびに機能的問題に加え，心理的因子を十分に考慮すべきであり，治療成績の評価において も客観的評価だけでなく，患者，術者あるいは第三者の主観的評価も検討する必要があります。特 に，外科的矯正治療における手術の成功が必ずしも患者に満足をもたらすとは限らないことから，患 者自身が術後の咬合や顔貌にどの程度満足しているのかは非常に興味深いところです。また，顎矯正 手術が社会心理学的に陽性の影響を及ぼすことは一般的に受け入れられていますが，心理学的問題を 抱える患者では適切なカウンセリングと慎重な対応をすべきであるとされています。

本シンポジウムでは「顎変形症患者の心理」をテーマに 3 名の先生方にご報告いただき，様々な角 度から「患者さんの考えていること，望んでいること」を明らかにしたいと思います。本シンポジウ ムが，患者に対する理解をより深めるための討論の機会になればと考えます。 


\section{顎変形症患者の心理と行動変容プロセスについて \\ Psychological state and behavior modification process on patients with dentofacial deformity}

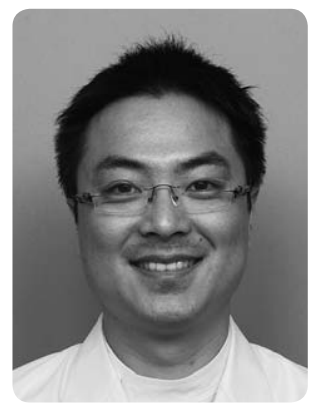

植田 紘貴

Hirotaka Ueda

鹿児島大学大学院医歯学総合研究科 歯科矯正学分野

Department of Orthodontics \& Dentofacial Orthopedics,

Kagoshima University Graduate School of Medical and Dental Sciences

顎変形症患者はどのような心理的プロセスを経て医療機関を受診するのでしょうか。顎変形症の患 者は，本人が自ら医療機関を受診することによってはじめて顎変形症と診断されますが，顎変形症の 様態であっても患者自らが積極的に受診行動を選択しない場合もあります。受診する（行動に移す）, 受診しない（行動に移さない）の判断には，何が影響を与えているのでしょうか。その背景を明らか にするために，1行動変容ステージモデル (心理と行動の関係), (2)自己の顔貌に対する身体認識 (ボディーイメージ), (3)自己への尊厳や自尊心（セルフエスティーム）等の観点から検討したいと思 います。

行動変容ステージモデルは, 心理的要因から人がある一定の行動をとるまでのプロセスを「無関心 期」「関心期」「準備期」「実行期」「維持期」の 5 つのステージに分けたもので, 治療の際には患者が どのステージにいるのかを把握することが重要となります。ボデイーイメージは, 自己身体に対する 肯定的または否定的な空間認識を示す概念で，その乘離が治療動機の一つであると同時に，患者の満 足度の程度に関連していると考えられることから, 外科的矯正治療を通じて, どのように自己への尊 厳や自尊心（セルフエスティーム）の回復が図られるのかは重要な論点であると考えられます。

顎変形症の治療プロセスの中で, 顔貌の改善を機に術後矯正治療や装置撤去後の保定のための通院 に対するモチベーションが下がる場合があります。このような問題を回避する上で，顎変形症患者の 心理的状態の把握と，心理状態に応じた行動変容技法の応用は心理的問題を抱える顎変形症患者の精 神的サポートになるだけでなく, 患者の治療への協力度や満足度に大きな影響を与える可能性があり ます。したがって，医療チームで患者の心理状態に関する情報を共有し，患者の自尊心の向上に繋が る積極的な働きかけを行うことが重要であると考えられます。 


\section{略 歴}

2005 年 3 月 岡山大学歯学部歯学科 卒業

2009 年 3 月 岡山大学大学院医歯薬学総合研究科 修了 博士 (歯学)

2009 年 4 月 岡山大学病院矯正歯科 医員

2010 年 4 月 鹿児島大学病院発達系歯科センター矯正歯科 助教

2014 年 4 月 鹿児島大学大学院医歯学総合研究科 歯科矯正学分野 助教 


\section{顎変形症患者が望む治療を考える}

ーアンケート調查と心理テストの結果から—

Desirable treatment for patients with jaw deformity:

Analysis of questionnaire study and psychological test

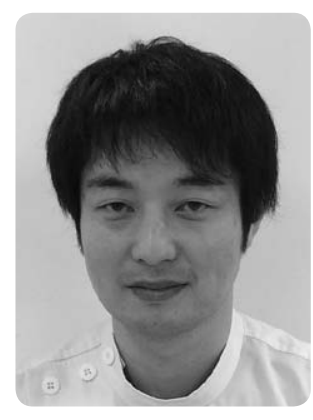

小島 拓

Taku Kojima

新潟大学大学院医歯学総合研究科 組織再建口腔外科学分野

Division of Reconstructive Surgery for Oral and Maxillofacial Region,

Niigata University Graduate School of Medical and Dental Sciences

外科的矯正治療は，顎変形症患者における咀嚼などの機能面だけでなく，顔貌などの形態的な面や 心理的な面にも大きな変化をもたらすと言われている。顎矯正手術による満足度は一般的に高いとさ れているが, 一方では治療結果に不満を持っている患者も少数おり, 特に心理学的に問題の多い患者 は術後の満足度が低くなる傾向があることが報告されている。したがって顎変形症患者の心理を把握 することは，治療方針を決定する上で重要であると考えられる。

顎変形症患者の心理学的特性についてはアンケート調査, 心理テスト, 面接法と様々な方法が報告 されている。われわれはこれまでに, 外科的矯正治療の結果を患者側の観点から評価するため郵送回 収法による術後アンケート調査を行ってきた。1970年代（Tomizawa ら：J Oral Surg 1981), 1980 年代（Nagamine ら：J Oral Maxillofac Surg 1986)，1990 年代（小林ら：日顎変形誌 2006）と 3 回 の調査を行っており, 今回, 2000 年代に当科で顎矯正手術を行った患者を対象に同様のアンケート 調査を行った。これらの結果は年代毎に結果が異なる部分があり，時代とともに患者の主訴や心理に 変化があることが推測された。一方，心理テストは心理学的特性を客観的に理解する上で有用である と言われている。われわれは，ミネソタ多面的人格目録を使用し，顎矯正手術が患者の心理面にどの ような影響を及ぼすのか評価を行った。その結果，顎矯正手術は患者の心理面に陽性の影響を及ぼす ことが示唆されたが，心理学的問題を抱える患者では注意が必要であると考えられた。実際，われわ れは顎矯正手術後に心理学的問題が表在化して対応に苦慮した症例を経験している。

われわれは，初診時ならびに手術直前に十分な医療面接を行い，個々の患者が抱える問題点を明確 にした上で，患者に満足してもらえる治療計画を立案することが重要であると考えている。特に，心 理学的問題を抱える患者では適切なカウンセリングを行い，慎重に対応すべきである。 


\section{略 歴}

2003 年 3 月 新潟大学歯学部歯学科 卒業

2007 年 3 月 新潟大学大学院医歯学総合研究科 修了

2008 年 7 月 新潟大学大学院医歯学総合研究科 組織再建口腔外科学分野 助教

2012 年 9 月 オランダ・マーストリヒト大学 頭蓋顎顔面外科学講座 留学

歯学博士

日本口腔外科学会専門医 


\section{外科的矯正治療患者の心理的変化}

一各治療段階における患者心理と QOL について—

The psychological changes of surgical

orthodontics patients

- Patient's psychology and QOL in each tratment phase -

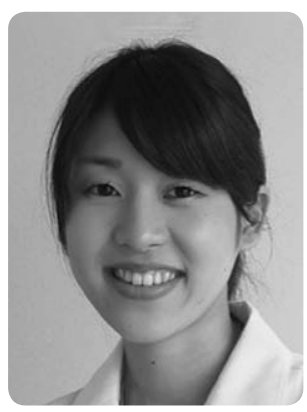

立木 千恵

Chie Tachiki

東京歯科大学 歯科矯正学講座

Department of Orthodontics, Tokyo Dental College

顎変形症患者の来院動機はアンケート調査の結果より, 主に「顔が気になる」と「かみ合わせが気 になる」がほとんどを占めます。そしておよそ $70 \%$ が自分にコンプレックスをもっていると回答し ました。外科的矯正治療は口腔機能と審美的な改善を目標に掲げるのはもちろんですが, このような 患者の社会心理面の向上も一つの治療目的となっています。従来より治療後における社会心理的な改 善については多く報告されていることからも示されるように，われわれ医療サイドは治療後における 変化に注目をおいてきました。

外科的矯正治療を通じて患者は，デンタルコンペンセートによる顔貌の一時的な悪化や咀嚼能率の 低下する術前矯正治療の期間を通過しなくてはなりません。さらに，顎矯正手術を控えたその時期 に，種々の治療に対する期待と不安を抱えていると考えます。治療上通過せざるをえないこの治療又 テージにおいて患者の心理はどのように働き，QOL はどのように変化していくのかをわれわれは把 握しなければならないと考えます。

外科的矯正治療は従来より様々な改良が試みられ，その治療予測と治療結果とを比較してみると精 度の高い治療結果を得ていることが研究結果より明らかになりました。これは治療期間を通じての診 断, 術前矯正治療後の最終治療計画立案, 顎矯正手術, 術後矯正治療の一連のクリニカルパスが成熟 した結果，治療結果の精度の向上として反映しています。しかし，治療中の患者への心理変化に対す る配慮はほとんどなされていないのが現状です。

外科的矯正治療の質の向上のためには，顎変形症患者への心理的配慮と QOL 低下への対応が 1 つ の検討課題と考えます。本講演では, 顔貌, 機能とともに変化する各治療段階における患者心理と QOL の変化を明らかにし, 今後の外科的矯正治療に求められることを考察していきたいと思います。 


\section{略 歴}

2006 年 3 月 東京歯科大学 卒業

2007 年 4 月 東京歯科大学 歯科矯正学講座 入局

2011 年 7 月 東京歯科大学 歯科矯正学講座 助教

2012 年旦本矯正歯科学会認定医 